\title{
Statistical Analysis of the Groundwater Samples from Bapatla Mandal, Guntur District, Andhra Pradesh, India
}

\author{
Sudhakar Gummadi ${ }^{1}$, Swarnalatha. $\mathrm{G}^{2}$, Z. Vishnuvardhan ${ }^{3}$, Harika.D ${ }^{4}$ \\ ${ }_{1,2}^{1}{ }^{4}$ Department of Environmental Sciences, Acharya Nagarjuna University, Guntur, India \\ ${ }^{3}$ Department of Botany, Acharya Nagarjuna University, Guntur, India
}

\begin{abstract}
Water is an elixir of life. It is an important component to human survival. Water should be purified for a better life style. It is the basic duty of every individual to conserve water resources. The present study attempts to bring an acute awareness among the people about the quality of ground water by taking water samples from specific locations for analysis. The experimental analysis was done for various Physico-chemical and biological parameters such as $\mathrm{pH}$, Electrical Conductivity, $\mathrm{TDS}, \mathrm{CO}_{3}^{2-}, \mathrm{TH}, \mathrm{Ca}^{2+}, \mathrm{Mg}^{2+}, \mathrm{Cl}, \mathrm{NO}_{3}^{-}, \mathrm{SO}_{4}{ }^{2-}$ , Turbidity, $\mathrm{Na}^{+}, \mathrm{K}^{+}, \mathrm{Fe}$, and $\mathrm{F}^{-}$etc., The results are compared with standards of WHO, USPH and BIS and ISIRI. In the present study, a statistical analysis for eight data points of drinking water at eight villages, of Guntur District has been done and the results were discussed here. The systematic correlation and regression analysis showed significant linear relationship among different pairs of water quality parameters.
\end{abstract}

Key words: Correlation and regression, Ground water, Parameters, Standards, Statistical analysis,

\section{INTRODUCTION}

Water quality performs important role for all living beings. The physical and chemical parameters of water play a significant role in classifying and assessing water quality. It is the basic duty of every individual to conserve water resources (Jothivenkatachalam, et al,. 2010),

The quality of surface water within a region is governed by both natural processes such as precipitation rate, weathering processes and soil erosion and anthropogenic effects such as urban, industrial and agricultural activities and the human exploitation of water resources (Liao S W et al., 2007; Mahyi A H et al 2005; Nouri J et al., 2008 and Jaryie H P et al., 1998).

Ground water quality has become an important water resources issue due to rapid increase of population, rapid industrialization, unplanned urbanization, flow of pollution from upland to lowland, and too much use of fertilizers, pesticides in agriculture (Joarder M A M, et al, 2008). In general weathering, dissolution and base-exchange processes control the levels of cationic concentrations in groundwater (Janardhana et al.2010).

It is important to know the quality of groundwater because it is the major factor which decides its suitability for domestic, agriculture and industrial purposes (Raju, et al, 2009).

The importance of groundwater as a fresh water source for drinking, industrial and domestic purposes is growing in most parts of world. Water scarcity is one of the major challenges in the environment which has resulted in the continent's underdevelopment, lack of safe drinking water and adequate sanitation. Fresh water makes up only about $2.5 \%$ of the total global water resource and the remainder is saltwater (Ranjan S P, et al., 2006).

Many investigations have been conducted on anthropogenic contaminants of ecosystems (Heikka, R.A, 2007) and reported that drinking water quality is affected by the presence of different soluble salts (Sonawane, V.Y. and Khole A M, 2010).

Groundwater is the prime resource of raw water under such conditions. One of the most significant environmental problems in coastal Andhra Pradesh, is the increase in salinity of the groundwater. The source of salinity and the mechanism of groundwater salinization in the coastal Andhra Pradesh are not known. Consequently there are several possible sources of salinity; solutes may be concentrated by evaporation of the flood water or the flow and groundwater seepage receives salt from the Bay of Bengal- Salt water intrusion, Determining the source of salinity and the mechanism of groundwater salinization is vital for future water management plans, including the design and drilling of new wells (Marie and Vengosh, 2001).

A systematic study of correlation and regression coefficients of the water quality parameters not only helps to assess the overall water quality but also to quantify relative concentration of various pollutants in water and provide necessary for implementation of rapid water quality management programmes. (Kumar $\mathrm{N}$ and Sinha D K, 2010; Dash J R et al,. 2006).

Many researchers have focused on the hydro-chemical characteristics and contamination of groundwater in different basins as well as in urban areas that resulted due to anthropogenic intervention, mainly 
by agricultural activities and domestic wastewater (Singh et al. 2008; Xiang et al. 2008, 2009; Shrestha et al., 2010).

In this present study, an attempt has been made to evaluate and improve the quality of ground water in Bapatla mandal area and thereby to analyze correlation and regression study of various PhysicoChemical parameters.

\subsection{Study area:}

\section{Materials And Methods}

The study area, Bapatla mandal is one of the major regions in Guntur district, Andhra Pradesh situated

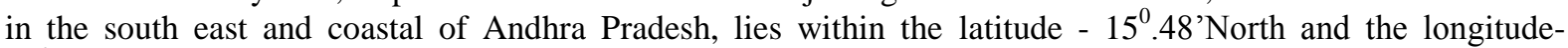
$80^{\circ} .17^{\prime}$ East. The locations of sample collection were near the residential and agricultural areas. Eight sampling stations were selected for the collection of ground water for this study in the March, 2011.

\subsection{Sampling and Method of analysis:}

The drinking water quality depends on many physico-chemical parameters and their concentrations, which are derived from laboratory tests of water samples. (Heydari M M et al., 2013).

Water samples were collected in clean polyethylene bottles from different sources viz. Hand pumps, open wells and other sources [Sharma et al., 2005].

A total of 8 water Samples per each station were collected in the selected regions in Bapatla Mandal viz., Marripudi(S1), Appikatla(S2), Poondla(S3), Murthinagaram(S4), Kondubotla varipalem(S5), Bapatla(S6), Muthayapalem(S7), Devinuthala(S8) (fig: 1). The water samples were collected carefully in new 500ml polyethylene bottles. (Sudhakar.G and Latha S G, 2013).

In the present study the temperature of the water Samples was in the range $25-30^{\circ} \mathrm{C}$. Fifteen parameters for the estimation of groundwater quality were observed such as: pH, Electrical Conductivity (EC), Total Dissolved Solids (TDS), Total Hardness(TH), Carbonates $\left(\mathrm{CO}_{3}{ }^{2-}\right)$, Calcium $\left(\mathrm{Ca}^{2+}\right)$, Magnesium $\left(\mathrm{Mg}^{2+}\right)$, Sulphates $\left(\mathrm{SO}_{4}{ }^{2-}\right)$, Chlorides $\left(\mathrm{Cl}^{-}\right)$, Nitrates $\left(\mathrm{NO}_{3}{ }^{-}\right)$, Sodium $\left(\mathrm{Na}^{+}\right)$, Potassium $\left(\mathrm{K}^{+}\right)$, Iron $(\mathrm{Fe})$, Fluoride $\left(\mathrm{F}^{-}\right)$, Turbidity $(\mathrm{T})$ by using standard techniques (WHO, 2004, APHA 1995).

The results of statistical analysis for important physico-chemical characteristics viz., Mean, Standard Deviation (SD), Standard Error (SE) and Coefficient of Variation (CV) have been presented in Table -1 and the values were compared with standard parameters in Table -2 .

The suitability of groundwater for drinking and other purposes may be assessed by comparing physical and chemical parameters of the study area with the guidelines recommended by World Health Organization (WHO, 2004).

Fig 1: Map of the study area showing the different sampling sites.

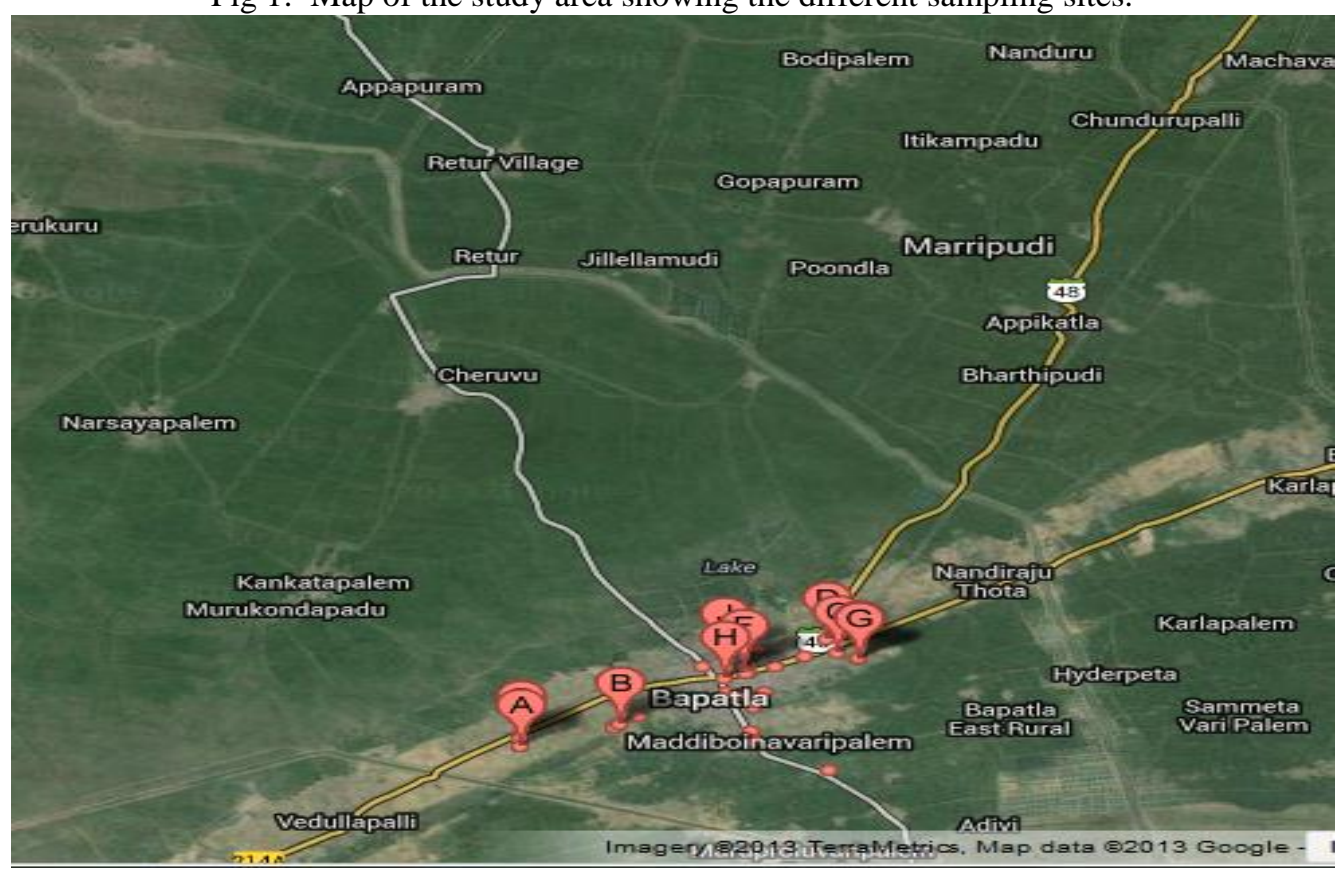




\subsection{Correlation coefficient and Linear Regression:}

In statistics, correlation is a broad class of statistical relationship between two or more variables. The correlation study is useful to find a predictable relationship which can be exploited in practice. In water quality it is used for the measurement of the strength and statistical significance of the relation between two or more parameters (Mehta, K.V., 2010).

Correlation analysis measures the closeness of the relationship between chosen independent and dependent variables. If the correlation coefficient is nearer to +1 or -1 , it shows the probability of linear relationship between the variables $\mathrm{x}$ and $\mathrm{y}$. The correlation between the parameters is characterized as strong, when it is in the range of +0.8 to 1.0 and -0.8 to -1.0 , moderate when it is having value in the range of +0.5 to 0.8 and -0.5 to -0.8 , weak when it is in the range of +0.0 to 0.5 and- -0.0 to -0.5 (Nair A G., 2005).

In this study, the relationship of water quality parameters with each other in the data of water analyzed was determined by calculating Karl Pearson's correlation coefficient, R, by using the formula as given below:

$$
R=\frac{\sum(X-\bar{X})(Y-\bar{Y})}{\sqrt{\sum(X-\bar{X})^{2} \sum(Y-\bar{Y})^{2}}}
$$

Where, $\mathrm{x}(\mathrm{x}=$ values of $\mathrm{x}$-variable, $\bar{X}=$ average values of $\mathrm{x})$ and $\mathrm{y}(\mathrm{y}=$ =values of $\mathrm{y}$-variable, $\bar{Y}=$ average values of y) represents two different water quality parameters. If the values of correlation coefficient ' $\mathrm{R}$ ' between two variables $\mathrm{x}$ and $\mathrm{y}$ are fairly large, it implies that these two variables are highly correlated.

To determine the straight linear regression, following equation of straight line can be used

$$
\mathrm{Y}=\mathrm{a}+\mathrm{bX} \quad \text { - }
$$

If the values of correlation coefficient ' $r$ ' between two variables $\mathrm{X}$ and $\mathrm{Y}$ are fairly large, it implies that these two variables are highly correlated. In such cases it is fissile to try linear relation in the form-

The values of empirical parameters ' $a$ ' and ' $b$ ' are calculated with the help of the following equation:

$$
\begin{gathered}
b=\frac{\sum X Y-\bar{Y} \sum Y}{\sum X^{2}-\bar{X} \sum Y} \\
a=\bar{Y}-b \bar{X}
\end{gathered}
$$

To study the correlation between various water quality parameters, the regression analysis was carried out using computer Microsoft Excel 2007.

\section{Results And Discussion}

The temperature of the water is in the range $27-33^{\circ} \mathrm{C}$. The important physico-chemical characteristics of analyzed water samples viz., Mean, Standard Deviation (SD), Standard Error (SE) and Coefficient of Variation (CV) have been presented in Table-2 and the values were compared with standard parameters in Table-2. The Coefficient of Variation observed for EC, TDS, Cl, F, and Fe were 55.39\%, 57.69\%, 65.86\%, 54.39\% and $115.25 \%$ and found to be very high. While the Coefficient of Variation for $\mathrm{pH}, \mathrm{T}, \mathrm{CO}_{3}, \mathrm{NO}_{3}, \mathrm{SO}_{4}, \mathrm{Ca}, \mathrm{K}, \mathrm{Na}$, $\mathrm{Mg}$ and $\mathrm{TH}$, found to be $33.33 \%, 18.12 \%, 24.31 \%, 32.43 \%, 20.48 \%, 44.74 \%, 29.68 \%, 31.93 \%, 31.40 \%$, and $23.27 \%$. It shows that variation in these parameters among its measured values at different locations was not high and variation range was narrow.

$\mathrm{pH}$ is considered as an important ecological factor and provides an important piece of information in many types of geochemical equilibriums or solubility calculations (Shyamala. R. et al,. 2008). the $\mathrm{pH}$ value of drinking water is an important index of acidity or alkalinity. A number of minerals and organic matter interact with one another to give the resultant $\mathrm{pH}$ value of the sample. In the present study $\mathrm{pH}$ ranges from 6.6-7.9, which lies in the range prescribed by WHO 2004 and APHA 1995).

In this study, the numerical values of correlation coefficient, $\mathrm{R}$ for the eight water quality parameters were tabulated in Table-3. It is shown that a single parameter analyzed has relationship with other parameters.

Highly positive correlation is observed between EC and TDS ( $\mathrm{R}=0.9674)$, between $\mathrm{Ca}^{2+}$ and TH $(\mathrm{R}=0.756)$, between $\mathrm{CO}_{3}$ and $\mathrm{K}(0.8667)$, and between $\mathrm{Na}$ and $\mathrm{TH}(0.6342)$.

Total hardness of water is caused by the presence of $\mathrm{Ca} \& \mathrm{Mg}$ salts (Kataria et al., 2011), and hardness plays role in heart diseases in human. Hardness above approximately $200 \mathrm{mg} / \mathrm{liter}$ may cause scales in water pipes and distribution systems. (Heydari M M et al., 2013), Table-2 shows all groundwater samples were exceeding the BIS standards.

Electrical conductivity of water is a direct function of its total dissolved salts (Harilal C.C et al, 2004). The level of TDS is one of the characteristics, which decides the quality of drinking water. In the present study, TDS ranged from 332.8-3146 mg/L. According to WHO and USPH total dissolved solid values for drinking 
water permissible minimum is $500 \mathrm{mg} / \mathrm{L}$, the maximum permissible limit is $1500 \mathrm{mg} / \mathrm{L}$. The analyzed data shows that three samples had more than the maximum permissible limit (Table-1). Water with high residue is normally less palatable and may induce an unfavorable physiological reaction in the transient consumer and even may cause gastrointestinal irritation (Adak M G, and Purohit K M, 2001). High level of TDS may aesthetically be unsatisfactory for bathing and washing (Jameel A A, and Sirajudeen J, 2006; Kumar M and Kumar R, 2013).

In the present study, the amount of sulphate ion is estimated to vary from $122.2-216 \mathrm{mg} / \mathrm{L}$. The maximum tolerance range for sulphate is $200-400 \mathrm{mg} / \mathrm{L}$. The excess amount of sulphate causes diarrhoea. Hence it is clear that all samples are free from sulphate problems.

The chloride content in the study samples lied between $119-750 \mathrm{mg} / \mathrm{L}$. chloride is normally the most dominant anion in water. According to WHO and BIS the permissible limit for chloride in drinking water is 250-mg/L (Jothivenkatachalam K, and Suresh K, 2008), high concentration of chloride is due to the invasion of domestic wastes and disposals by human activities (Jha A.N. and Verma P.K., 2000). In the present study; the value of chloride content in four samples has been found to be high, which can cause corrosion and pitting of iron plates or pipes.

The ground water contamination is due to the leaching of nitrate present on the surface with percolating water. Here, the nitrate range lied between 0.5 to $1.98 \mathrm{mg} / \mathrm{l}$, all samples were in the permissible range.

The percolation of phosphatic fertilizers from the agricultural runoff from the nearby fields and discharge of domestic wastes or the wastes from the surrounding industries increases the fluoride values. (Bhosle A.B et al., 2001). The fluoride range observed was 0.5 to $1.15 \mathrm{mg} / \mathrm{L}$, compared to BIS all samples were in permissible limits.

$\mathrm{K}$ and $\mathrm{Fe}$ ranges were also within the permissible limits in all the study sites and the $\mathrm{Na}$ and $\mathrm{Mg}$ ranges were very high in all the samples compared to WHO standards. This might be due to dissolution of precipitates of $\mathrm{CaCO}_{3}$ and $\mathrm{Ca} \mathrm{Mg}\left(\mathrm{CO}_{3}\right)_{2}$ during recharge (Datta and Tyagi 1996; Lakshmanan et al. 2003).

Comparing the results obtained in this study with drinking water quality standards issued by WHO, BIS, USPH, ISIRI it is found that most of the water samples are not potable. The results of the statistical analysis of ground water quality parameters viz., mean, standard deviation and coefficient of variation and the correlation matrix for various variables is depicted (Table- $2 \& 3$ ). It is evident that distribution of TDS, TH, $\mathrm{Ca}, \mathrm{CO} 3$, and $\mathrm{Na}$ were significantly correlated $(\mathrm{r}>0.5)$. The Positive correlation is obtained between 53 unions (i.e, $50 \%$ of the total number) and negative correlation is seen in the rest of the 52 unions (i.e, $50 \%$ of total number). Highly positive correlation is observed between EC and TDS (0.9604) while highly negative correlation coefficient is seen among TDS and SO4 (-0.0938), T and K+ (-0.0179). The linear regression analyses have been carried out for the water quality parameters which are found to have better and higher level of significance in their correlation coefficient. The regression equations obtained from the analysis are given in the Table-4. The different dependent characteristics of water quality were calculated using the regression equation by substituting the values for the independent parameters in the equations. The experimentally estimated and calculated values using the regression equations are given in Table-5. Hence it can be concluded that the correlation studies of the water quality parameters have a great significance in the study of water resources.

Table-1: Physicochemical parameters of drinking water from Bapatla mandal, Coastal Andhra Pradesh

\begin{tabular}{|c|c|c|c|c|c|c|c|c|c|c|c|c|c|c|c|}
\hline & S1 & S2 & S3 & S4 & S5 & S6 & S7 & S8 & Max & Min & Range & Mean & SD & SE & $\begin{array}{ll}\text { CV } \\
\%\end{array}$ \\
\hline $\mathrm{pH}$ & 7.22 & 7.25 & 7 & 6.77 & 6.7 & 6.82 & 7.39 & 6.86 & 7.39 & 6.70 & 0.69 & 7.00 & 2.34 & 0.82 & 33.33 \\
\hline $\mathrm{EC}$ & 3260 & 2620 & 812 & 2040 & 1143 & 4848 & 1722 & 2080 & 4848.00 & 812.00 & 4036.00 & 2315.62 & 1282.70 & 453.71 & 55.39 \\
\hline $\mathrm{T}$ & 2.3 & 1.4 & 1.7 & 2.5 & 2.4 & 2.1 & 2.2 & 1.9 & 2.50 & 1.40 & 1.10 & 2.06 & 0.37 & 0.13 & 18.13 \\
\hline TDS & 1523 & 1703 & 332.8 & 1326 & 742.9 & 3146 & 1119 & 1356 & 3146.00 & 332.80 & 2813.20 & 2931.83 & 829.13 & 293.19 & 57.97 \\
\hline $\mathrm{CO}_{3}$ & 485 & 320 & 312 & 275 & 215 & 315 & 385 & 310 & 485.00 & 215.00 & 270.00 & 327.12 & 79.54 & 28.12 & 24.31 \\
\hline $\mathrm{Cl}$ & 190 & 750 & 150 & 430 & 160 & 119 & 400 & 410 & 750.00 & 119.00 & 631.00 & 326.12 & 214.81 & 26.86 & 65.87 \\
\hline $\mathrm{NO}_{3}$ & 1.47 & 0.5 & 1.8 & 1.82 & 1.22 & 1.56 & 1.25 & 1.98 & 1.98 & 0.50 & 1.48 & 1.45 & 0.47 & 0.17 & 32.43 \\
\hline $\mathrm{SO}_{4}$ & 122.2 & 155.7 & 216 & 138 & 130.4 & 169.8 & 125 & 151 & 216.00 & 122.20 & 93.80 & 151.01 & 30.94 & 10.94 & 20.49 \\
\hline $\mathrm{F}$ & 0.2 & 1.12 & 1 & 1.15 & 1.5 & 1.2 & 1 & 0.1 & 1.15 & 0.10 & 1.05 & 0.90 & 0.49 & 0.17 & 54.39 \\
\hline $\mathrm{Ca}$ & 215 & 150 & 200 & 320 & 122 & 90 & 140 & 106 & 320.00 & 90.00 & 230.00 & 110.42 & 75.11 & 26.55 & 44.74 \\
\hline $\mathrm{K}$ & 6.8 & $5 . .5$ & 3.9 & 4.9 & 2.5 & 4.5 & 6.9 & 4.5 & 6.90 & 2.50 & 4.40 & 4.93 & 1.47 & 0.52 & 29.69 \\
\hline $\mathrm{Na}$ & 578.4 & 234.9 & 246.78 & 321.8 & 335.2 & 289.4 & 341.5 & 418.3 & 578.40 & 234.90 & 343.50 & 345.70 & 110.42 & 39.04 & 31.43 \\
\hline $\mathrm{Mg}$ & 215.9 & 240.14 & 138.6 & 127.5 & 149.35 & 185 & 216.9 & 315.2 & 315.20 & 127.50 & 187.70 & 198.50 & 62.36 & 22.05 & 31.40 \\
\hline $\mathrm{Fe}$ & 0.01 & 0.001 & 0.1 & 0.002 & 0.1 & 0.003 & 0.02 & 0.1 & 0.10 & 0.00 & 0.10 & 0.04 & 0.05 & 0.02 & 115.25 \\
\hline $\mathrm{TH}$ & 689 & 454.2 & 415 & 620 & 398 & 420 & 413 & 418 & 689.00 & 398.00 & 291.00 & 478.40 & 111.36 & 39.37 & 23.28 \\
\hline
\end{tabular}

*Except $\mathrm{pH}$ and $\mathrm{EC}$ in $(\mu \mathrm{mhos} / \mathrm{cm})$ remaining all Parameters are in $\mathrm{mg} / \mathrm{L}$ 
Table-2: Comparison of drinking water quality with drinking water standards

\begin{tabular}{|l|c|c|c|c|c|c|}
\hline Parameters & WHO & USPH & European Standards & BIS & ISIRI1053 & Present study value \\
\hline $\mathrm{pH}$ & $6.9-8.5$ & $6.0-8.5$ & $6.5-9.0$ & $6.5-8.5$ & $6.5-9.0$ & $6.7-7.39$ \\
\hline $\mathrm{EC}$ & 300 & 300 & 400 & - & 300 & $812-4848$ \\
\hline Turbidity & - & - & - & 10 & - & $1.4-2.5$ \\
\hline $\mathrm{TDS}$ & $500-1500$ & 500 & 500 & 500 & 1500 & $332.8-3146$ \\
\hline $\mathrm{CO}_{3}$ & - & & - & 300 & - & $215-485$ \\
\hline $\mathrm{Cl}$ & $200-600$ & 250 & 250 & 250 & 250 & $119-750$ \\
\hline $\mathrm{NO} 3$ & $40-50$ & - & - & 45 & 50 & $0.5-1.98$ \\
\hline $\mathrm{SO} \mathrm{F}_{4}$ & $200-250$ & 250 & - & 200 & 250 & $122.2-216$ \\
\hline $\mathrm{F}$ & $1-1.5$ & - & - & 1.2 & 1.5 & $0.1-1.15$ \\
\hline $\mathrm{Ca}$ & $75-200$ & 100 & 100 & - & - & \\
\hline $\mathrm{K}$ & 20 & - & - & - & 20 & $2.5-6.9$ \\
\hline $\mathrm{Na}$ & $50-60$ & - & - & - & 200 & $234.9-578.4$ \\
\hline $\mathrm{Mg}$ & $30-150$ & 30 & - & 50 & 30 & $127.5-315.2$ \\
\hline $\mathrm{Fe}$ & 2 & - & - & 1 & - & $0.001-0.1$ \\
\hline $\mathrm{TH}$ & $100-500$ & 500 & - & 300 & 500 & $398-689$ \\
\hline
\end{tabular}

*Except $\mathrm{pH}$ and $\mathrm{EC}$ in $(\mu \mathrm{mhos} / \mathrm{cm})$ remaining all Parameters are in $\mathrm{mg} / \mathrm{L}$

WHO-World Health Organization, USPH-United states Public Drinking water Standards, BIS-Bureau of Indian Standards,

ISIRI- Institute of Standards and industrial research of Iran Drinking water

Table-3: Correlation Coefficients among Various water quality Parameters

\begin{tabular}{|c|c|c|c|c|c|c|c|c|c|c|c|c|c|c|c|}
\hline Parameters & $\mathrm{pH}$ & EC & Turbidity & IDS & $\mathrm{CO}_{3}{ }^{2-}$ & $\mathrm{Cr}$ & $\mathrm{NO}_{3}{ }^{-}$ & $\mathrm{SO}_{4}{ }^{2-}$ & $F^{-}$ & $\mathrm{Ca}^{2-}$ & $\mathbf{K}$ & $\mathrm{Na}^{+}$ & $\mathrm{Mg}^{2-}$ & $\mathrm{Fe}$ & $\mathrm{TH}$ \\
\hline $\begin{array}{l}\mathrm{pH} \\
\mathrm{EC}\end{array}$ & $\begin{array}{l}1 \\
0.0194\end{array}$ & 1 & & & & & & & & & & & & & \\
\hline $\begin{array}{l}\text { Turbidity } \\
\text { TDS } \\
\mathrm{CO}^{3}{ }^{2 \cdot} \\
\mathrm{Cl}^{2} \\
\mathrm{NO}_{3}{ }^{-} \\
\mathrm{SO}_{4}{ }^{2 .}\end{array}$ & $\begin{array}{l}-0.3669 \\
-0.0679 \\
0.7424 \\
0.4064 \\
-0.5002 \\
-0.1717\end{array}$ & $\begin{array}{l}0.0306 \\
0.9674 \\
0.3563 \\
-0.0812 \\
-0.0844 \\
-0.1177\end{array}$ & $\begin{array}{l}1 \\
-0.002 \\
-0.0127 \\
-0.4822 \\
0.3915 \\
-0.6054\end{array}$ & $\begin{array}{l}1 \\
0.1608 \\
0.012 \\
-0.1136 \\
-0.0938\end{array}$ & $\begin{array}{l}1 \\
-0.0274 \\
-0.0414 \\
-0.2501\end{array}$ & $\begin{array}{l}1 \\
-0.5423 \\
-0.1994\end{array}$ & $\begin{array}{l}1 \\
0.2445\end{array}$ & 1 & & & & & & & \\
\hline $\begin{array}{l}\mathrm{F} \\
\mathrm{Cg}^{-2} \\
\mathrm{~K}^{-} \\
\mathrm{Na}^{+} \\
\mathrm{Mg}^{2+} \\
\mathrm{Fe} \\
\mathrm{TH}\end{array}$ & $\begin{array}{l}-0.2707 \\
0.2921 \\
0.8367 \\
0.1541 \\
0.3455 \\
-0.405 \\
0.1268\end{array}$ & $\begin{array}{l}-0.1415 \\
-0.2423 \\
0.3182 \\
0.1981 \\
0.221 \\
-0.6586 \\
0.2472\end{array}$ & $\begin{array}{l}0.0916 \\
0.3345 \\
-0.0179 \\
0.4706 \\
-0.4063 \\
-0.1049 \\
0.4201\end{array}$ & $\begin{array}{l}-0.0029 \\
-0.3221 \\
0.2133 \\
0.0139 \\
0.2275 \\
-0.6331 \\
0.0737\end{array}$ & $\begin{array}{l}-0.6469 \\
0.112 \\
0.8667 \\
0.661 \\
0.3398 \\
-0.4396 \\
0.5479\end{array}$ & $\begin{array}{l}-0.0331 \\
0.112 \\
0.3482 \\
-0.2681 \\
0.4326 \\
-0.3532 \\
0.0149\end{array}$ & $\begin{array}{l}-0.396 \\
0.2435 \\
-0.2043 \\
0.2805 \\
-0.0898 \\
0.3848 \\
0.1378\end{array}$ & $\begin{array}{l}0.1412 \\
-0.0691 \\
-0.4 \\
-0.5885 \\
-0.2218 \\
0.3494 \\
-0.4097\end{array}$ & $\begin{array}{l}1 \\
0.0005 \\
-0.4615 \\
-0.7454 \\
-0.7036 \\
-0.0974 \\
-0.3832\end{array}$ & $\begin{array}{l}1 \\
0.2036 \\
0.114 \\
-0.7454 \\
-0.2984 \\
0.7456\end{array}$ & $\begin{array}{l}1 \\
0.4279 \\
0.3616 \\
-0.6729 \\
0.4889\end{array}$ & $\begin{array}{l}1 \\
0.347 \\
-0.0479 \\
0.6342\end{array}$ & $\begin{array}{l}1 \\
0.054 \\
-0.1462\end{array}$ & $\begin{array}{l}1 \\
-0.5177\end{array}$ & 1 \\
\hline
\end{tabular}

Strong-3, Moderate-5, Weak-45, Negative-52.

Table-4: Linear correlation coefficient $\mathrm{R}$ and regression equation for some pairs of parameters which have significant value of correlation

\begin{tabular}{|c|c|c|c|c|}
\hline \multirow{2}{*}{$\begin{array}{c}\text { Pair of } \\
\text { Parameters }\end{array}$} & \multirow{2}{*}{ R-Value $(n=8)$} & \multicolumn{2}{|c|}{ Regression Coefficient } & \multirow{2}{*}{ Regression equation } \\
\hline & & A & $\mathrm{B}$ & \\
\hline pH-TH & 0.1268 & 6.861 & 0.0002 & $\mathrm{pH}=0.0002(\mathrm{TH})+6.861$ \\
\hline $\mathrm{PH}-\mathrm{K}$ & 0.8367 & 6.2803 & 0.1459 & $\mathrm{pH}=0.1459(\mathrm{~K})+6.2803$ \\
\hline $\mathrm{PH}-\mathrm{CO}_{3}$ & 0.7425 & 6.2202 & 0.0023 & $\mathrm{pH}=0.0023\left(\mathrm{CO}_{3}\right)+6.2202$ \\
\hline EC-TDS & 0.9675 & 211.068 & 1.4967 & $\mathrm{EC}=1.4967=(\mathrm{TDS})+211.068$ \\
\hline EC-K & 0.3183 & 940.327 & 278.541 & $\mathrm{EC}=278.541(\mathrm{~K})+940.327$ \\
\hline $\mathrm{T}-\mathrm{Na}$ & 0.2473 & 1.5113 & 0.0015 & $\mathrm{~T}=0.0015(\mathrm{Na})+1.5113$ \\
\hline TDS-SO ${ }_{4}$ & 0.4707 & 1786.08 & -2.516 & TDS $=-2.516\left(\mathrm{SO}_{4}\right)+1786.08$ \\
\hline TDS-Na & -0.0939 & 1369.75 & 0.1050 & TDS $=0.1050(\mathrm{Na})+1369.75$ \\
\hline TDS- $\mathrm{CO}_{3}$ & 0.0140 & 857.545 & 1.6768 & TDS $=1.6768\left(\mathrm{CO}_{3}\right)+857.545$ \\
\hline TDS-Cl & 0.0121 & 1390.906 & 0.0465 & $\mathrm{TDS}=0.0465(\mathrm{Cl})+1390.90$ \\
\hline $\mathrm{CO} 3-\mathrm{K}$ & 0.8668 & 94.8848 & 47.035 & $\mathrm{CO} 3=47.0359(\mathrm{~K})+94.8848$ \\
\hline $\mathrm{Cl}-\mathrm{TH}$ & 0.0150 & 312.323 & 0.0288 & $\mathrm{Cl}=0.028(\mathrm{TH})+312.323$ \\
\hline $\mathrm{Ca}-\mathrm{TH}$ & 0.7457 & -72.723 & 0.5029 & $\mathrm{Ca}=0.5029(\mathrm{TH})+-72.723$ \\
\hline $\mathrm{Na}-\mathrm{TH}$ & 0.6343 & 44.9006 & 0.6289 & $\mathrm{Na}=0.628(\mathrm{TH})+44.9006$ \\
\hline
\end{tabular}




\section{Conclusion}

The quality of ground water sample collected from eight different locations of Bapatla mandal, Guntur district analyzed and on the basis of these analytical findings, the following conclusions can be drawn. The $\mathrm{pH}$ of the entire water samples is well within the permissible limits. The $\mathrm{Ca}$ and $\mathrm{Na}$ values of all the water samples for some of the samples are within permissible limits and some of the samples are beyond the limits. Chlorides content of four samples are in higher range than permissible limits. Sulphate content for all samples is within permissible limits. The reason for dwindling quality of water in this region may be due to over consumption for drinking, domestic and agricultural purposes. Hence, rapid and reliable monitoring measures are essential for keeping a close watch on water quality and health environment. Based on the correlation regression study, it can be concluded that all the parameters are more or less correlated with each other. The linear correlation is very useful to get fairly accurate idea of quality of the groundwater by determining a few parameters experimentally

\section{Reference}

[1] Jothivenkatachalam, K., Nithya A and Mohan S C, (2010). Correlation analysis of drinking water quality in and around Perur block of Coimbatore District, Tamil Nadu, India, Rasayan Journal 13. Chemistry, 3(4): 649654.

[2] Liao S W, Gau H S, Lai W L, Chen J J, and Lee C G, (2007), J. Environ. Manag., 88 (2), 286.

[3] Mahvi A H, Nouri J A, Babiei A, and Nabizadeh R, (2005), Int. J. Environ. Sci. Tech., 2 (1), 41.

[4] Nouri J A, Karbassi R, and Mirkia S, (2008), J. Environ. Sci. Tech., 5 (1), 43.

[5] Jarvie H P, Whitton B A, and Neal C, (1998), Sci. Total Environ., 210-211, 79.

[6] Joarder M A M, Raihan F, Alam J B, and Hasanuzzaman S, (2008), Int. J. Environ. Res.2(3), 291.

[7] Janardhana RN, Shukla UK, Prahlad R, (2010) Hydrogeochemistry for the assessment of groundwater quality in Varanasi: a fast urbanizing center in Uttar Pradesh, India. Environ Monit Assess 173:279-300.

[8] Raju N J, Ram, P., and Dey, S. (2009). Groundwater Quality in the Lower Varuna River Basin, Varanasi District, Uttar Pradesh. Journal of the Geological Society of India, 73(2), 178-192.

[9] Ranjan S. P, Kazama S and Sawamoto M. (2006). Effects of climate and land use changes on groundwater resources in coastal aquifers. Journal of Environmental Management, 80(1), 25-35

[10] Heikka R.A. (2007), Multivariate monitoring of water quality: A case study of Lake Simple, Finland. J. Chemomet., 22, 747-751.

[11] Sonawane V.Y. and Khole A M, (2010), Water quality of some drinking waters in Parbhani city: a case study, Journal of Chemical Pharmaceutical Research, 2(5): 104107.

[12] Marie A and Vengosh A. (2001). Sources of salinity in ground water from Jericho area, Jordan Valley. Ground Water, 39(2), 240248 .

[13] Kumar N and Sinha D K, (2010), Drinking water quality management through correlation studies among various physicochemical parameters: a case study, International Journal of Environmental Sciences, 1(2): 253259.

[14] Dash J R, Dash P C and Patra H K, IJEP, 26 (6), 550 (2006).

[15] Singh A.K, Mondal G.C, Kumar S, Singh TB, Tewary BK, Sinha. A, (2008) Major ion chemistry, weathering processes and water quality assessment in upper catchments of Damodar River basin, India. Environ Geol 54:745-758.

[16] Xiang H, Mika S, Bu D, Egil T, Gjessing, (2008), Water quality in the Tibetan plateau Metal contents of four selected rivers. Environ Poll 156(2):270-277.

[17] Xiang H, Mika S, Gjessing ET, Vogt RD, (2009), Water quality in the Tibetan plateau: major ions and trace elements in the hard waters of four major Asian rivers. Environ Poll 407(24):270-277.

[18] Shrestha RA, Kafle BK, Sillanpaa. M, (2010) Water quality of Dhulikhel area. Nepal Res J Chem Environ 14(2):36-38.

[19] Heydari M M, Abasi A, (2013), Correlation Study and Regression Analysis of Drinking Water Quality in Kashan City, Iran Seyed Mohammad Rohani and Seyed Mohammad Ali HosseiniMiddle-East, 2013 J. Sci. Res., 13 (9): 1238-1244.

[20] Sharma, J.D., Sharma P, Jain P and Sohu D, (2005), Chemical Analysis of Drinking Water of Sanganer Tehsil, Jaipur District, Int Jrnl of Envi Sci and Tech, 2(4): 373-379.

[21] Sudhakar. G, and Latha S G,(2013), Seasonal Variation of Ground-Water Analysis from Bapatla Mandal, Guntur District, Andhra Pradesh Int. Jrnl of sci \& research, 10.12 .

[22] WHO. (2004). Guidelines for drinking water Quality. Geneva.

[23] APHA, (1995), Standard Methods for Examination of Water and Waste Water, $19^{\text {th }}$ edn., American Public Health Association, Washington, D.C.

[24] Mehta, K.V, (2010), Physicochemical characteristics and statistical study of groundwater of some places of Vadgam taluka in Banaskantha district of Gujarat state (India), Journal of Chemical Pharmaceutical Research, 2(4): 663670.

[25] Nair A J, Abdullan G, Mohamad I and Fadiel M M, 2005, Poll Res., 24(1): 1-6.

[26] Shyamala R., Shanthi M. and Lalitha P. (2008), Physicochemical analysis of borewell water samples of Telungupalayam area in Coimbatore District, Tamilnadu, India, E-Journal of chemistry, 5(4), 924-929.

[27] Kataria H.C, Gupta M, Kumar M, Kushwaha S, Kashyap S, Trivedi S, Bhadoriya R and Bandewar N K, (2011), Study of Physico-chemical Parameters of Drinking Water of Bhopal city with Reference to Health Impacts Curr. World Environ, Vol. 6(1), 95-99.

[28] Harilal C.C., Hashim A., Arun P.R. and Baji S., (2004), J Ecology Environ Conservation, 10(2), 187-192.

[29] Adak M G and Purohit K M (2001), Poll. Res., 20, 575.

[30] Jameel A A and Sirajudeen J, (2006), India. Enviro. Monitoring and assessment, 123, 299.

[31] Kumar M and Kumar R, (2013), Assessment of Physico-Chemical Properties of GroundWater in Granite Mining Areas in Goramachia, Jhansi, UP.India., Int. Res. J. Environment Sci. Vol. 2(1), 19-24.

[32] Jothivenkatachalam K, and Suresh K, (2008), NEPT Journal. 7(2), 283

[33] Jha A.N. and Verma P.K., (2000), Physico-chemical properties of drinking water in town area of Godda district under Santal Pargana (Bihar), India, Poll. Res., 19(2), 75-85.

[34] Bhosle A.B., Narkhede R.K., Rao B and Patil P.M.,(2001), Studies on the fluoride content of Godavari river water at Nanded, Eco. Env. and Conserv. 7(3), 341-344.

[35] Datta, P S and Tyagi, S K, (1996). Major ion chemistry of groundwater in Delhi area: Chemical weathering processes and groundwater flow regime.Journal of the Geological Society of India, 47, 179-188.

[36] Lakshmanan E, Kannan K, and Senthil Kumar M, (2003). Major ion chemistry and identification of hydrogeochemical process of groundwater in part of Kancheepuram district, Tamilnadu, India.Journal of Environmental Geosciences 10(4), $157-166$. 